\title{
The Influence of Contextual Factors on the Multinationality-Performance Relationship: A Conceptual Model
}

\author{
Florian Christopher Fleming ${ }^{1}$ \& José Ednilson de Oliveira Cabral ${ }^{2}$ \\ ${ }^{1}$ The Faculty of Business Administration, Deggendorf Institute of Technology, Germany \\ ${ }^{2}$ Centre for Social Sciences, Universidade de Fortaleza, Ceara, Brazil \\ Correspondence: Florian Christopher Fleming, The Faculty of Business Administration, Deggendorf Institute of \\ Technology, 94469 Deggendorf, Germany.
}

Received: March 28, 2016

Accepted: April 13, 2016

Online Published: April 22, 2016

doi:10.5430/ijba.v7n3p15

URL: http://dx.doi.org/10.5430/ijba.v7n3p15

\begin{abstract}
Our general objective is to present an extension of the established theories of the multinationality-performance relationship. In methodological terms, it is an in-depth study based on an extensive review of the literature. The proposed conceptual model includes the contextual factors, like Firm, Industry and Home-Country Factors. Through the contextual factors, the model gives a broader insight and a detailed explanation of the influencing factors of the multinationality-performance relationship. This study explains by the conceptual model the current status quo of literature in the field of multinationality-performance relationship and analyzes its shape and behavior.
\end{abstract}

Keywords: multinationality, performance, multinationality-performance relationship, contextual factors, conceptual model

\section{Introduction}

Over the last couple of years, the globalization and the interconnection of the global economy has purged forward tremendously. According to the World Investment Report of the United Nations Conference on Trade and Development (UNCTAD), the number of companies operating abroad was at end of the 1960s about 10,000. By the end of the year 1990 the total number rose to 35,000. With 82,000 companies operating in foreign location, the number reached its peak in 2008. Companies operating abroad are very important for the global economy. The UNCTAD estimates that the sum of all Multinational Enterprises (MNE) and their subsidiaries account for one third of world trade in goods and services. In 2009 the UNCTAD estimated that 80 million employees or even more were working for MNEs or their subsidiaries.

The framework "markets and hierarchies" (Hymer, 1960; Williamson, 1975) gives an explanation for the existence and motivation of multinational enterprises (MNEs). According to the internationalization theory, MNEs are companies which are able to increase its value by geographical diversification and transferring intangible assets across national borders (Buckly and Casson, 1976; Morck and Yeung, 1991).

That is why the question arises, whether enhanced geographical internationalization provide higher firm performance. This question has been discussed by many scholars in the field of International Business for the last three decades. Several empirical and theoretical studies appeared and tried to link multinationality to the performance of companies with various results (Contractor, 2007; Lu and Beamish, 2004; Kirca et al., 2011; Yang and Driffield, 2012). The studies had controversial outcomes which show the importance of the topic in the current literature of International Business.

The results are different. Many argue that the use of different statistical methods (regression or Anova), different databases; different performance variables (ROA or ROI) or not sticking to sample heterogeneity are all possible reasons for the controversial or even conflicting results. Kirca et al. (2012) state that many factors influencing the Multinationality-Performance (M-P) relationship weren't considered in the investigated studies. Therefore, Kirca et al. (2012) developed a conceptual model to explain why results are different and what factors are important for the shape and outcome of the M-P relationship. Although this conceptual model explains the results of former studies very well and introduces contextual factors like firm-, industry- and country-specific factors, it doesn't explain all factors in detailed form and forgets to indicate all influences on the M-P relationship. Hence our paper enhances the model by 
Kirca et al. (2012) by giving better explanations of the performance determinants and showing a more detailed insight of the various influences on the M-P relationship based on current literature. This article has the following contribution:

- First our article examines in 2.1 the advantages and disadvantages of geographic internationalization postulated in literature and their connection to the M-P relationship.

- Secondly our paper shows whether there is a significant M-P relationship in literature or not. In the next step we conclude the expected shape and the potential influences on the M-P relationship (2.2).

- In the next step (Model Development and Discussion) the article develops a conceptual model based on Kirca et al. (2012) that enables a more context-based understanding of the M-P relationship. Additionally, it fills in the gaps of explanation and observation of influence on the M-P relationship from Kirca et al. (2012).

- Finally, our article provides a usable insight for managers and policy makers as to which factors influence firm performance and can enhance the probability of success.

\section{Literature Review}

The literature provides several theoretical explanations of the nature of the M-P relationship. Therefore, we first discuss the costs and benefits of internationalization. Afterwards the empirical literature is reviewed regarding the M-P relationship. In that part the paper explains the shape and the different possible outcomes of the relationship.

\subsection{Costs and Benefits of Internationalization}

Multinationality in literature is described in controversial ways and often related to the definition of MNEs. We define multinationality as the extent to which a company extends or expands their activities beyond the borders of its domestic base into a market in a new geographic country or region to undertake value-adding activities. Therefore, companies can reduce their cost of production, enhance the productivity and improve the revenue of their value-chain. An example for this is the recent movement of Japanese pharmaceutical firms to the U.S. due to better R\&D possibilities there. Another example is the outsourcing of call centres in the 1980s and 1990s from U.S. American software companies to the low labour cost countries like El Salvador, India, Philippines or India. This caused an outsource of about 5 million call centre jobs. These examples show how and to what extent companies are exploiting the resources at foreign locations by configuring their value-chain activities (Kogut, 1985; Hitt, Tihanyi Miller, and Connelly, 2006; Kirca, Roth, Hult, and Cavusgil, 2012).

The literature has not been able to enforce a comprehensive theory on the relationship between internationalization and corporate success (Glaum and Oesterle, 2007). The assumption of a positive relationship between internationalization and corporate performance is mostly justified by the resource-based view (Grant, 1991; Annavarjula and Beldona, 2000). The application of the competitive advantage-creating resources, which were developed on the domestic market, are leading to a successful engagement in foreign markets (Lu and Beamish, 2004). Furthermore, internationalization gives companies the possibility to exploit arbitrage opportunities and market imperfections across countries and regions, which can lead to more competitiveness and more gains (Dunning and Lundan, 2008).

Another justification of positive effects of internationalization is submitted in the form of the flexibility of organizations. A company, operating in many countries, is able to react fast to changes on national markets by shifting production or the diversion of goods flows.

The probable most significant fact is the possibility to transfer resources into foreign markets to achieve both economy of scale and scope. Internationalization promotes the diversification of the companies' risk. For example, the Brazilian manufacturer of beauty products Natura generated in 2005 just $2.8 \%$ of total sales revenues abroad (Jones and Pinho 2006). This can be a big risk for the company because of its dependence on the political and economic conditions in Brazil. Thus, a company can reduce its risk and increase the company's risk management by being active in several countries, whose markets are not perfectly correlated (Annavarjula and Beldona, 2000; Oesterle and Richta, 2009). The economy of scale describes the enhanced productivity and efficiency, which occurs with the increasing size of a firm (Kotabe, Srinivasan, and Aulakh, 2002; Tallman and Li 1996).

Another argument for a positive relationship between internationalization and the company's success is provided by the theory of organizational learning. Therefore, an enterprise, operating in different countries, may benefit because it owns the diversity of information of different locations, which cannot be achieved by restricting the activities on the domestic market (Ghoshal, 1987). This can be for example the adaption from products to the needs of customers 
in a specific region or country. This advantage of capturing information around the globe can enhance the competitive advantages compared to companies, operating only in the domestic market (Oesterle and Richta, 2009).

The mentioned arguments, which pointed out the positive relationship between multinationality and performance, are confronted with several arguments, justifying a negative impact of multinationality on the success of enterprises.

The main argument for the negative effects of internationalization on performance is the costs of coordination and control (Gomes and Ramaswamy, 1999). The increasing degree of a company`s internationalization enhances the complexity of business activities and its business structure. This may be due to different legal frameworks in different countries, rising costs of logistics, cultural diversity, the information asymmetries between company management and foreign units or the size of the organization. The coordination and control costs reduce the profit generated by the internationalization and may even overcompensate it (Grant, 1987; Denis, Denis, and Yost, 2002).

Another negative factor influencing the company's success is seen in the competitive disadvantage of foreign companies compared to native or already established companies in the relevant foreign market. This competitive disadvantage is due to a lack of information about the local environment and the risk of product discrimination by the customers (e.g. German products during World War II). This can be overcome over time, which can be observed by the success of German products after World War II (Barkema, Bell, and Pennings, 1996). Moreover, the internationalization of businesses not only provides positive effects in terms of risk diversification, but it also increases the risks in form of incomplete information, reduced possibilities to control abroad operating manager and the increasing volatility risk of the exchange rate. The risk associated with foreign activities is therefore regarded as the net effect (Reeb, Kwok, and Baek, 1998).

It can be seen that the performance advantages of multinationality will reach their limit when internal governance costs exceed the benefits provided by the economies achieved and thus, the range of resources used and scope of governance exceeds managerial capabilities.

\subsection{Empirical Review of the Multinationality-Performance Relationship}

The different arguments of the internationalization theories do not have a common answer to the M-P relationship. Therefore, various studies have been conducted to verify this relationship empirically (Glaum and Oesterle, 2007). Some contributions show, that there is not a significant or only a very weak impact on corporate performance (e.g. Tallman and Li, 1996).

In other studies, a positive linear correlation is determined (e.g. Grant, 1987). This relationship indicates that internationalization of companies affects the firm`s performance in a positive manner. More recent research of the positive linear relationship suggests, that it is moderated by other Firm Factors like the capabilities in the firm's resort of R\&D and marketing (Kotabe et al., 2002; Thomas and Eden, 2004) or by enhanced administrative intensity (Pan and Tsai, 2012).

Further studies found positive but diminishing returns in the M-P relationship. This theory says that the expansion of companies initially affects corporate success positively, but over time, the marginal returns will diminish (Thomas and Eden, 2004). So the M-P relationship is positive but the performance diminishes with further internationalization (Gomes and Ramamswamy, 1999).

Since the 1990s, non-linear M-P relationships were developed and investigated a different shape of the relationship. These studies are characterized by a U-shaped relationship and included the organizational learning theory into their research (Ruigrok and Wagner, 2003). The theory suggests that companies initially undergo negative performance (e.g. the moving costs of production, marketing expenses, transaction costs). Nevertheless, enterprises learn from the initial costs and problems and after a certain time the firm learns how to adapt to the circumstances, to reduce costs, to become more competitive in the foreign market and thus gain positive performance.

Other researchers have disputed the U-shape and invented an inverted-U-shape relationship between multinationality and performance (Gomes and Ramaswamy, 1999; Hitt, Hoskisson, \& Kim, 1997). The inverted-U relationship says that the relationship becomes negative over time because of the enhancing incurred costs of the more complex organizations. The performance is initially positive until a certain level of the curvilinear relationship is reached. Afterwards the company's performance becomes negative. In the study of Hitt et al. (1997), it can be observed that a further geographic diversification at a certain point will increase the costs of coordination, control and the management of the international network to that extent, that the costs overweigh the performance made by the foreign activities. Therefore, they describe the relationship as an inverted U-shape relationship with initially positive and after the turning point negative performance as the level of internationalization increases further. 
Gomes and Ramaswamy (1999) added to the study of Hitt et al. (1997) the possibility of using arbitrage differences in foreign economies through the use of home-based resources, skills and competencies to diversify the costs of product development (Thomas and Eden, 2004). Nevertheless, through enhanced expansion the MNE can grow to a size, where it is opposed by a more complex, inflexible and more cost intensive organizational structures. Additionally, the expansion can include countries with higher cultural and geographical distance, which can raise the transaction costs (e.g. logistics, coordination costs). According to their study the M-P relationship is a nonlinear function, initially increasing and afterwards decreasing revenues as the costs of further expansion will overweigh the gains of internationalization (Thomas and Eden, 2004; Qian, Li, Li, and Qian, 2008)

This was offset by the development of the "Multistage Theory" or the "3-stage Theory" (Lu and Beamish, 2004; Thomas and Eden, 2004; Contractor, 2007; Andersen, 2008). According to both models an S-shaped relationship exists between the degree of internationalization and the company's success, which is divided into three phases. In the first phase the degree of internationalization of a company is low. Here the costs of internationalization outweigh the positive effects. In the second phase profits can be generated by an increase of internationalization until a level in the third phase is reached, in which the gained profits in foreign activities are overcompensated by the resulting costs of control and coordination (Contractor, 2007; Lu and Beamish, 2004). The heterogeneity of the results of recent studies is explained by the differences in the individual studied samples, where only for sections of the S-curve statistically significant correlations are proven (Glaum and Oesterle, 2007). The literature review shows, that the empirical studies do not differentiate on various factors, which influence the M-P relationship. Firm, Industry, and Home-Country factors are not included in the recent research (Buckley and Casson, 2009; Kirca et al., 2011). The current literature explains and examines the M-P relationship without taking into account the capabilities and weaknesses companies face to maximize the gain of international expansion. The issue is that some companies have capabilities due to their industry, their country origin or their firm factors, which make them more capable to expand effectively to foreign markets. Big differences between the various industries can be seen. For example, Castellani and Zanfei (2007) conclude that manufacturing companies with the highest degree of internationalization are characterized by the highest productivity premia, the highest R\&D efforts and the highest innovative performances. Moreover, the manufacturing companies can transfer more easily knowledge-based assets to foreign countries than companies of the service industry.

These finding give an insight into the M-P relationship and show its complexity, since individual companies strategies moderate the strength and direction of the relationship (Kotabe et al., 2002). Kotabe et al. (2002) showed that the R\&D and marketing intensity can moderate the M-P relationship. Furthermore Pan and Tsai (2012) found out that the administrative intensity moderates the relationship between internationalization and performance. The consequence is that many factors are not considered in the empirical research. Therefore, we want to build a conceptual model upon the existing research, which fills in the gap mentioned. The developed conceptual model is based on the model, presented in Kirca et al. (2012).

\section{Model Development and Discussion}

Kirca et al. (2011) stated, that the firm-specific assets have the strongest impact on the extent to which multionationality relates to financial performance. Therefore, it is essential for the explanation of the M-P relationship to investigate these firm-specific assets in a more detailed way. For this reason, in this article the model of Kirca et al. (2012) was chosen and developed further. Here the firm-specific assets are explained by the contextual factors (Firm Factors, Industry Factors, Home-Country Factors) and are brought together with the M-P relationship to investigate and explain it more precisely, which can be seen in Figure 1.

In the following sections we discuss the different contextual factors and their influence on the firm performance. The contextual factors, which affect the M-P relationship, are divided into three factor categories: Firm, Industry Factors and Home-Country Factors. All contextual factors influence the shape of the M-P-relationship. The reason for this is the importance of the transfer and arbitrage possibilities of the contextual factors across borders (Kirca et al., 2012). That is why we state like Kirca et al. (2012), that the context can set specific constraints and opportunities that either enhance or reduce the effects of multinationality on a firm`s performance. 


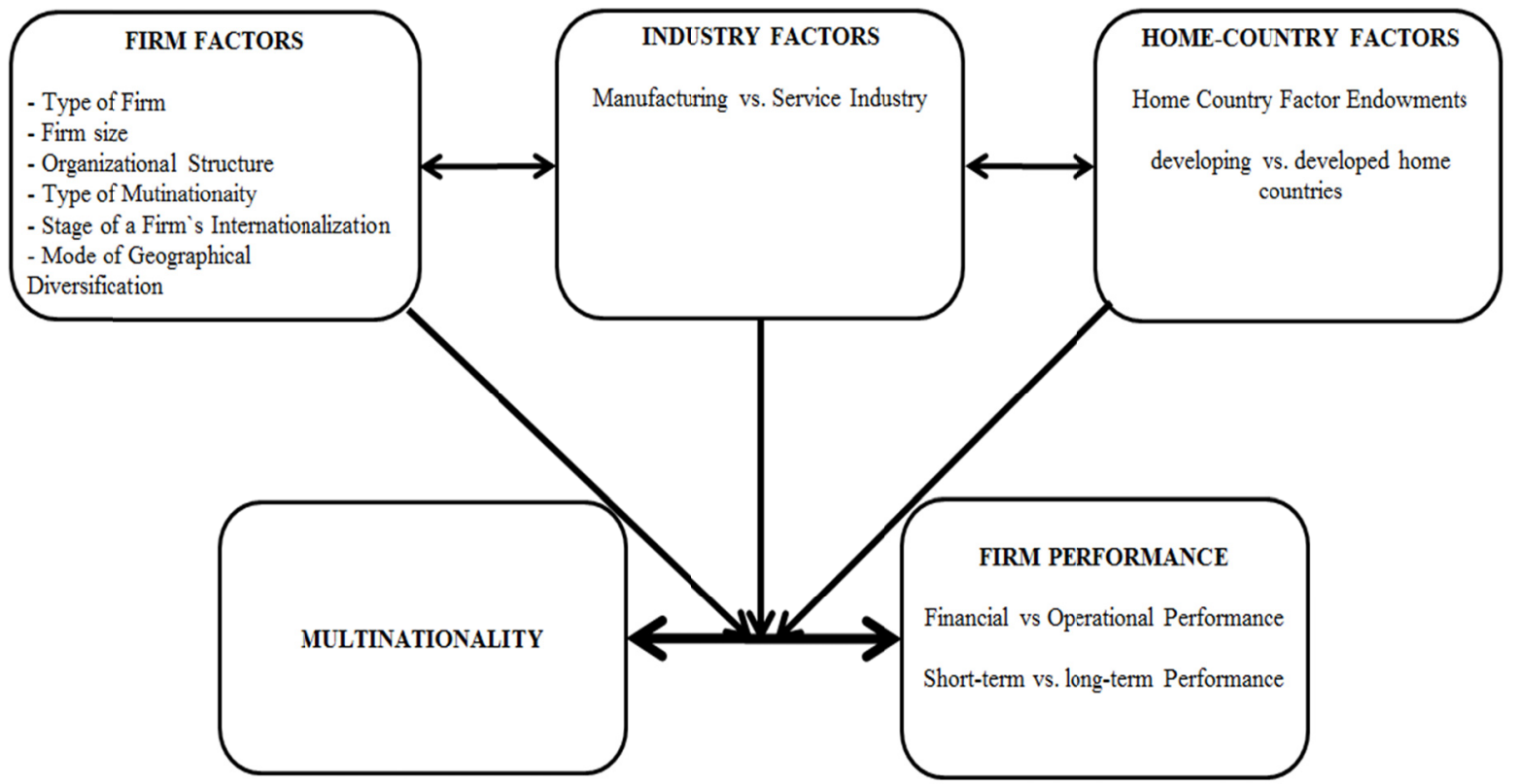

Figure 1. Conceptual Model of the influence of contextual factors on the M-P-relationship

Source: Model is based on assumptions of Kirca et al. (2012)

\subsection{Firm Factors}

The scholars in international business assume that companies decide their internationalization strategy based on the most beneficial foreign location for their specific activities. Companies try to internalize markets until the point where the profit of further international expansion overweighs the incurred total costs (Buckley, 1988). In addition, Morck and Yeung (1991) conclude that the enlargement of the firm`s value due to internationalization is a function of the relationship between firm multinationality and its possession of intangible assets. This assumes that the Firm Factors function as a presenter of the M-P relationship. Intangible assets therefore are likely characterized as public good, thus their value is enlarged directly correlated to the scope and range of the markets in which the firm is operating. The consequence is that the intangible assets can act as public goods that mean that the value rises, if companies diversify more geographically. Thereby can be concluded that firm performance is positively correlated with internationalization in the presence of Firm Factors (Kirca et al., 2011; Morck and Yeung, 1991).

The type of firm is an important context derived from the literature. The type of firm can be explained in two ways: privately- or government -owned companies. Estrin (2012) found out that the different roles state-owned enterprises (SOE) play in different economic and political systems, can be translated into different propensities to engage in international business. Furthermore the study concludes that SOEs are less likely to internationalize and are dependent from the political and institutional development of the SOE's country of origin (Estrin, 2012). Furthermore, SOEs are not considered as efficient as their privatized counterpart, that's why their firm performances due to further geographical diversification are not as high privatized companies. Nevertheless through their governmental support many companies can have advantages in their internationalization process, through their better power position and their financial benefits (Büge, Sztajerowska, Egeland, \& Kowalski, 2013).

Over the last few decades a new phenomenon can be seen in this context: The Born Globals. Born Globals are characterized as new firms which have limited foreign business units and little institutional knowledge. The knowledge of Born Globals is codified, experiential, and stored with qualified researchers with a high degree of similarity in knowledge. This makes clear and good communication on complicated issues within the company very important. The internalization of Born Globals is very dependent on the current level of knowledge. The firm's current level of knowledge defines the constraints for future internalization strategies. This includes the adaptability and flexibility of firms. Adaptation is made possible, as Born Globals are not bound by specific knowledge and successful decision experiences of the past. The internationalization process of Born Globals is characterized by the strategy of exploration. The ability of innovation and the evaluation of new business opportunities is a soft and 
highly important knowledge of Born Globals. In selecting foreign markets and foreign clients, Born Globals accumulate knowledge through establishing an optimal number of ties abroad as they are a source of referral. New ties, through a feedback process, increase the current stock of business and institutional knowledge in Born Globals. This increased stock of resources and knowledge in Born Globals allows them to engage in further internationalization. The competitive advantage of Born Globals is their high level of knowledge intensity which means they possess the knowledge and ability to develop new products (Sharma and Blomstermo, 2003). Born Globals can internationalize more effective and may have therefore a better M-P relationship, but it depends on the country of origin (Home-Country Factors) and the industry in which they operate (Hutchings, Chetty, and others, 2012).

The Firm size of companies has often been taken as a determinant to examine the company's competitive advantages in the international business literature ( $\mathrm{Lu}$ and Beamish, 2004). Larger companies benefit from interacting and reacting fast on foreign markets due to their powerful strategic setting. Furthermore, they profit from economies of scope and scale, are able to prevent smaller firms from market entrance, gaining access to market customers, suppliers and other sparse resources (Gaba, Pan and Ungson, 2002). Moreover, larger corporations have the power to invest more in R\&D to create innovation, to conduct aggressive expansion and to be capable to bear the risks of geographical internationalization and the incurred costs of it. In addition, the role of scale plays an important role for companies. They have the ability and bargaining power to handle the risk by risk diversification and get better deals out of negotiations with host country governments or institutions. Through the fact that larger firms have access to more assets and resources, they tend to be more risk takers in context of international expansion (Brewer, 1993). The consequence is larger firms are able to generate higher gains and profitability out of internationalization compared to their smaller counterparts due to their possession of more essential intangible assets (Kirca et al., 2012).

Today organizational structure plays a main role in the effectiveness and the probability of companies being successful abroad. Hitt et al. (1998) researched the optimal structure for companies dealing with internationalization. They found out that companies should enhance their flexibility to be able to react and act fast to the uncertainty of the environmental setting in nowadays business world. Some scholars state that companies have higher levels of administrative intensity when expanding internationally because of the uncertain environment (Sine, Mitsuhashi, and Kirsch, 2006). Further geographical diversification and the enhanced environmental complexity can tire out the capabilities of managers (Siddhartan and Lall, 1982). This development emphasizes a high complex administrative intensity and therefore the managers' tasks grow (Dunning, 1993). Other factors which influences the administrative intensity and though the organizational structure are the transfer of knowledge and other intangible assets within the international network of a company. Thus, if the geographic diversification is rising, more control and coordination will be required to preserve the profitable performance. The management team is demanded to have a higher administrative intensity to cope with increasing complexity and uncertainty of enhancing the geographical internationalization (Pan and Tsai, 2012).

The type of multinationality is an important factor that explains the M-P relationship (Thomas and Eden, 2004). In this paper we differentiate the type of multinationality into two types, which have various effects on the success of companies operating abroad.

The first type of internationalization is the depth. The depth describes the extent to which firms use tangible and intangible assets to create value from their international activities (e.g. foreign assets to total assets or foreign sales to total sales). Annarvajula and Bedona (2000) define this type of internationalization as the foreign production presence or the degree to which the enterprise is engaged in production-based activities. The depth of internationalization also explains the foreign market penetration that means the dependence of a firm on the foreign markets. The depth internationalization answers the question as to what percent the international activities of a company are abroad. (Thomas and Eden, 2004)

The second type of internationalization is the breadth. It describes the country scope, which can be defined as the geographic range of the firm's international activities (Goerzen and Beamish 2003). The breadth answers the question as to how wide the range of the global activities of the enterprise is. The number of countries a company operating is an example of used measurement (Thomas and Eden, 2004). The breadth of internationality is connected to the corporate success stronger than the depth. The reason for this is that enhanced breadth of international activities allows the top managers to assign a higher share of a firm's total activities to foreign locations and to gain economies of scope and scale with a wider geographical diversification (Thomas and Eden, 2004; Kirca et al., 2012). Furthermore, a wider range of international activities permits companies to take arbitrage possibilities of operations across borders and to benefit from location-based advantages more efficiently. The reason is that the breadth of 
internationalization is strongly beneficially connected to flexibility, organizational learning and the capability to be active in highly competitive markets (Goerzen and Beamish, 2003; Kogut and Zander, 1993). In addition, a higher level of breadth can save companies for the volatility of fluctuations in sales by diversifying the risks over a greater number of countries and markets. Goerzen and Beamish (2003) found that multinational depth is negatively related to firm performance while breadth is positively related to firm performance. In contrast, Allen and Pantzaalis (1996) found that there may be a trade-off between breadth and depth. Kirca et al. (2012) proposes that the benefits of multinationality for revenue generation activities are higher than its profit maximization benefits because firm internationalization initially concentrates on the exploitation of intangible assets across geographic markets.

The stage of a firm 's internationalization, the trade-off between costs and profits have been of interest in literature in recent years. The stage of a firm's internationalization in literature is often defined as the degree of internationalization. It is marked by the shape of its relationship: linear, U-, inverted-U or S-shape (Kirca et al., 2012). According to the literature the stage is responsible for the performance of a firm's internationalization. For example, a company operating in an S-shape M-P relationship will have initially (a low degree of internationalization) low or negative firm performance. In contrast a higher degree of internationalization may generate a positive or higher firm performance. This shows the importance of the stage of a firm`s internationalization regarding the M-P relationship.

The mode of geographical diversification plays a key role in describing the M-P relationship of companies. It explains what countries or regions a company is expanding to. This paper distinguishes between four modes: the intra-, interregional, regional and country diversification.

Intraregional diversification is defined as the geographical dispersion into countries or regions near to the home country. Interregional diversification functions as the counterpart and is defined as the expansion into countries or regions different from the home country. Companies expand abroad to get access to certain capabilities and to entry into new markets (Contractor, 2007; Lu and Beamish, 2004). The fact that regions differ in their resources and their settings makes it essential for companies implementing the interregional diversification strategy, to ensure the company`s flexibility, international capabilities and resources. Thereby they can profit from the expansive learning possibilities given by this strategy (Goerzen and Beamish, 2003). Additionally, companies can enhance their strategic management and their flexibility through having access to a further enlarged international network, which can raise the ability of control, coordination and operational efficiency (Qian, Khoury, Peng, \& Qian, 2010). The interregional diversification has an inverted-U-shaped relationship between the level of interregional diversification and firm performance (Qian et al., 2010). Interregional diversification can have positive revenues when the degree of such diversification is low. Further diversification can lead to a negative relationship between interregional diversification and corporate success if the level of diversification is getting higher (Qian et al., 2010). The current empirical research found out that international business activities are determined by companies operating on an intraregional basis (Rugman and Oh, 2013). The empirics from Rugman and Oh (2013) suggest that the world's largest companies are very much home region based in their activities of assets, sales and subsidiary locations.

Country diversification is defined by Li and Qian (2005) as the geographical diversification into individual foreign countries. For example, an US-based company builds subsidiaries in Brazil and South Korea at the same time. These two countries are different from the home country and are as well different from each other. In contrast regional diversification is an expansion into a set of countries, which are less culturally and geographically distant. An US-based company expands and builds subsidiaries in South America for example. Through the fewer amounts in distance of both the physicality and the culture this should reduce the costs of coordination, control and transaction. Moreover, due to Li and Qian (2005) the low distance influences the strategy of internationalization and therefore the expected performance. Regional and country diversifications don't result in equivalent results or in same incurred total costs of international diversification. The literature in international business proposes that the standardization of production and products is possible for homogeneous countries (Tallman and $\mathrm{Li}, 1996$ ). The homogeneous setting offers the possibility to have identical market characteristics and thereby to introduce similar services or products more easily. That is why the incurred costs can be reduced and economies of scope and scale can be achieved by the possible standardization. Additionally companies are able to build up synergies because the developed capabilities, knowledge and competencies in one country can slightly be transferred to countries within the same region with low physical and cultural distance (Tallman and Li, 1996; Pan and Tsai, 2012). These aspects show that expansion in homogeneous regions can increase profits and reduce costs for companies. A higher level of country diversification can lower firm performance because of the enhanced cultural and physical differences within the company and countries. The question whether having operations in a multiple or in a single region is dependent on the awareness of the differences between the countries and the capabilities of companies to deal with it (Pan and Tsai, 2012). 
Companies which aren't highly regionally diversified, need a mechanistic structure because of the certain and predictable environment. Centralized control and resource allocation are measures to enhance the operational efficiency of companies. High diversified countries in contrast should install an organic structure with a decentralized decision-making system, which is more flexible and can react better to the uncertain environment operating in (Pan and Tsai, 2012). Managers have to take into account the several possible outcomes of the different diversification possibilities which can influence in various ways the M-P relationship and should therefore chose the best mode according to their strengths and weaknesses.

\subsection{Industry Factors}

Industry Factors have a high influence on the performance related to the international expansion of companies. The Industry Factors are described through the different branches like the manufacturing or service related industries. Various industrial aspects and conditions may lead to different cost-benefit dynamics which can result in different firm performances. These industry factor cost-benefits dynamics can vary over time, for example the use of communication technologies and information can enhance the capability to manage activities in complex internationalized company structures (Juul Andersen, 2008).

The M-P relationship was often researched in this context, for example the comparison of the manufacturing and service branches (Capar and Kotabe, 2003). Many differences can be seen between these two sectors. The most important is the intangible nature of services, the fact that in the service industry the production and consumption processes cannot be separated. Another difference is the customer participation in the production process and the perishableness of services (Capar and Kotabe, 2003; Kotabe et al., 2002; Kirca et al., 2012). Empirical research state that companies operating in manufacturing, trading, and knowledge-based industries show positive performance relationships whereas firms in capital-based service industries show negative performance relationships (Juul Andersen, 2008). Furthermore the operational performance enhances earlier than the financial performance of companies operating with high R\&D intensities (Kotabe et al., 2002). There are four explanations for the effect and the weaker M-P relationship of the service industry compared to the manufacturing industry:

(1) The initial investments and transaction costs are higher, because it is difficult to transfer the knowledge and the intangibility of services (Capar and Kotabe, 2003; Hennart, 2007; Kirca et al., 2012);

(2) Moreover the costs of operation due to the heterogeneity of services and the fact that consumption and production processes cannot be separated, is high. That is why service firms may not benefit from economies of scale (Kirca et al., 2012);

(3) Service companies are strictly controlled and regulated by governments and other institutions (e.g. Basel II in the EU). This prevents the service industry to gain to the same extent gains from economies of scope and scale as the manufacturing industry (Kirca et al., 2012);

(4) Furthermore it is difficult to adapt the services to the needs of customers in foreign international markets because of their intangible nature. This can lead to higher incurred costs of adaptation than in the manufacturing industry (Kirca et al., 2012; Knight et al., 1999).

These arguments give a brief insight that the total costs of exploitation and transfer of firm-specific assets are much higher for firms operating in the service industry than for manufacturing firms (Kirca et al., 2012). Hence the empirical evidence (Kirca et al., 2012; Juul Andersen, 2008) provides strong support for the proposition that the performance effects of multinational expansion is confounded by industry factor conditions.

\subsection{Home-Country Factors}

The M-P relationship is also influenced by the Home-Country Factors, which are defined by the home country factor endowments (e.g. human resources, capital accumulation financial resources or physical infrastructures) and the institutional home country characteristics (e.g. legal, political, societal institutions)(Kirca et al., 2012; Hitt, Tihanyi, Miller, and Connelly, 2006).

Yang and Driffield (2012) examine in their study, that companies out of the USA make higher profits due to internationalization. The reason therefore is that non-US firms are confronted with limited and often small home market size, which makes it eligible to internationalize early and effectively abroad. The origin of companies can be differentiated as companies based in developing economies (e.g. Brazil, Russia, India and China) and companies based in advanced economies (e.g. Europe, North America and Japan). Firms from developing economies may yield lower revenues from international expansion than firms from developed economies (Cuervo-Cazurra, 2008). Firms from advanced economies benefit from several advantages like a more efficient institutional system in their home 
country. These institutional advantages can reduce costs for foreign expansion (Kirca et al., 2012). Furthermore, they often have a higher degree of competiveness due to the fact that they are used to full competition in their home country. Moreover, developed countries have advanced institutions providing companies with high-skilled labour and the possibility to create leading-edge knowledge or innovation to succeed in international competition. From these arguments can be concluded that companies home-based in developed countries have higher levels of Contextual Factors and are able to exploit and transfer more easily and efficiently their assets and goods to gain higher revenues in foreign markets than firms from developing countries (Kirca et al., 2012). Kirca et al (2011) found out, that although firms from advanced economies with high advertising intensity and R\&D profit from multinationality, the profits of multinationality for companies of developed economies are more limited. In contrast the rising of recent MNE of developing countries suggest that these firms have the ability to adapt and learn faster than their counterparts in developed countries (Thomas and Eden, 2004). MNEs especially from Latin America emerged fast because they are often family-owned which enhances the flexibility, decision making and enables a strong leadership in the company (Castro Olaya, Castro Olaya, and Jaller Cuéter, 2012). Their expansion is based on conquesting knowledge, new innovations, new capabilities and gaining access to new markets (Kirca et al., 2011).

\section{Conclusion}

Despite a large number of studies on the relationship between internationalization and firm performance there is unfortunately not a complete model that summarizes all the findings in literature. Our conceptual model summarizes the most important findings in a conceptual model. The model explains the contextual factors: Firm, Industry and Home-Country factors, which have been developed by Kirca et al. (2012). This article closes the gap with additional literature. In addition, our work describes the factors and their impact detailed on the results of the M-P relationship. We show in a simplified form, that some factors have strong and some have lesser influence.

Furthermore, the model shows that the M-P relationship is very complex and many more determinants should be included and explained. Our model indicates a positive relationship between internationalization and firm performance, which is consistent with the recent literature.

Our study suggests that the effects of further internationalization on corporate success depend on Firm Factors, Industry Factors and Home-Country Factors. Interestingly is the fact that the stage of a firm 's internationalization and the firm size are not considerable significant factors, which influence the shape of the M-P relationship (Kirca et al., 2012). Additionally we summarized that MNEs have a strong home region effect across assets and sales (Rugman and Oh, 2013). That means that the Home-Country Factor is overweighing the Firm Factors. This implicates that factor endowments delivered by the country of origin are more important than the Firm Factors. Our investigations also show that the Industry Factors are as important as the Home-Country Factors. This implies that police makers can influence the internationalization success of the companies operating in their home country through new laws, but cannot influence the endowments given by the industry branch (e.g. manufacturing or service industry).

Finally, managers observe in the model what individual factors they possess and can predict the chances of profits abroad. Moreover, they may eventually influence the corporate success by adjusting the Firm Factors (like e.g. organizational strategy, multinationality). Nevertheless, for future research we suggest that more factors like the mode of entry should be included in our model and should test it empirically.

\section{References}

Allen, F., Qian, J., \& Qian, M. (2005). Law, finance, and economic growth in China. Journal of financial economics, 77(1), 57-116. http://dx.doi.org/10.1016/j.jfineco.2004.06.010

Allen, L., \& Pantzalis, C. (1996). Valuation of the operating flexibility of multinational corporations. Journal of international business studies, 633-653. http://dx.doi.org/10.1057/palgrave.jibs.8490147

Andersen, T. J. (2008). Multinational performance relationships and industry context. SSRN Working Paper Series. http://dx.doi.org/10.2139/ssrn.1120734

Annavarjula, M., \& Beldona, S. (2000). Multinationality-performance relationship: A review and reconceptualization. The International Journal of Organizational Analysis, 8(1), 48-67. http://dx.doi.org/10.1108/eb028910

Barkema, H., Bell, J., \& Pennings, J. M. E. (1996). Foreign entry, cultural barriers and learning. Strategic management journal, 151-166. http://dx.doi.org/10.1002/(SICI)1097-0266(199602)17:2\%3C151::AID-SMJ799\%3E3.0.CO;2-Z 
Brewer, T. L. (1993). Government policies, market imperfections, and foreign direct investment. Journal of International Business Studies, 101-120. http://dx.doi.org/10.1057/palgrave.jibs.8490227

Buckley, P. J. (1988). The Limits of Explanation: Testing the Internalization Theory of the Multinationial Enterprise. Journal of International Business Studies, 19(2), 181-193. http://dx.doi.org/10.1057/palgrave.jibs.8490382

Buckley, P. J., \& Casson, M. (1976). The future of the multinational enterprise (Vol. 1). London: Macmillan. http://dx.doi.org/10.1007/978-1-349-02899-3

Buckley, P. J., \& Casson, M. C. (2009). The internalisation theory of the multinational enterprise: A review of the progress of a research agenda after 30 years. Journal of International Business Studies, 40(9), 1563-1580. http://dx.doi.org/10.1057/jibs.2009.49

Büge, M., Sztajerowska, M., Egeland, M., \& Kowalski, P. (2013). State-Owned Enterprises. OECD Trade Policy Papers No. 147.

Capar, N., \& Kotabe, M. (2003). The relationship between international diversification and performance in service firms. Journal of International Business Studies, 34(4), 345-355. http://dx.doi.org/10.1057/palgrave.jibs. 8400036

Castellani, D., \& Zanfei, A. (2007). Internationalisation, innovation and productivity: how do firms differ in Italy?. The world economy, 30(1), 156-176. http://dx.doi.org/10.1111/j.1467-9701.2007.00875.x

Castro Olaya, J., Castro Olaya, J., \& Jaller Cuéter, I. (2012). Internationalization patterns of multilatinas. AD-Minister, (21), 33-54.

Contractor, F. J. (2007). Is international business good for companies? The evolutionary or multi-stage theory of internationalization vs. the transaction cost perspective. Management International Review, 47(3), 453-475. http://dx.doi.org/10.1007/s11575-007-0024-2

Cuervo-Cazurra, A. (2008). The multinationalization of developing country MNEs: The case of multilatinas. Journal of International Management, 14(2), 138-154. http://dx.doi.org/10.1016/j.intman.2007.09.001

Denis, D. J., Denis, D. K., \& Yost, K. (2002). Global diversification, industrial diversification, and firm value. The Journal of Finance, 57(5), 1951-1979. http://dx.doi.org/10.1111/0022-1082.00485

Dunning, J. H. (1993). Internationalizing Porter's diamond. MIR: Management International Review, 7-1

Dunning, J. H., \& Lundan, S. M. (2008). Multinational enterprises and the global economy. Edward Elgar Publishing.

Estrin, S. (2012). The Internationalization of State Owned Enterprises: The Impact of Political Economy and Institutions. London Business School.

Gaba, V., Pan, Y., \& Ungson, G. R. (2002). Timing of entry in international market: An empirical study of US Fortune 500 firms in China. Journal of International Business Studies, 39-55. http://dx.doi.org/10.1057/palgrave.jibs.8491004

Ghoshal, S. (1987). Global strategy: An organizing framework. Strategic Management Journal, 8(5), 425-440.

Glaum, M., \& Oesterle, M.-J. (2007). 40 years of research on internationalization and firm performance: More questions than answers?. Management International Review, 47(3), 307-317. http://dx.doi.org/10.1002/smj.4250080503

Goerzen, A., \& Beamish, P. W. (2003). Geographic scope and multinational enterprise performance. Strategic Management Journal, 24(13), 1289-1306. http://dx.doi.org/10.1002/smj.357

Gomes, L., \& Ramaswamy, K. (1999). An empirical examination of the form of the relationship between multinationality and performance. Journal of International Business Studies, 173-187. http://dx.doi.org/10.1057/palgrave.jibs.8490065

Grant, R. M. (1987). Multinationality and Performance among British Manufacturing Companies. Journal of International Business Studies, 18(3), 79-89. http://dx.doi.org/10.1057/palgrave.jibs.8490413

Grant, R. M. (1991). The Resource-Based Theory of Competitive Advantage: Implications for Strategy Formulation. California Management Review, 33(3), 114-135. http://dx.doi.org/10.2307/41166664

Hennart, J.-F. (2007). The theoretical rationale for a multinationality-performance relationship. Management International Review, 47(3), 423-452. http://dx.doi.org/10.1007/s11575-007-0023-3 
Hitt, M. A., Hoskisson, R. E., \& Kim, H. (1997). International diversification: Effects on innovation and firm performance in product-diversified firms. Academy of Management journal, 40(4), 767-798. http://dx.doi.org/10.2307/256948

Hitt, M. A., Tihanyi, L., Miller, T., \& Connelly, B. (2006). International Diversification: Antecedents, Outcomes, and Moderators. Journal of Management, 32(6), 831-867. http://dx.doi.org/10.1177/0149206306293575

Hutchings, K., Chetty, S., \& others. (2012). Born-globals and culturally proximate markets. Management International Review, 52(3), 425-460.

Hymer, S. (1960). On multinational corporations and foreign direct investment. The Theory of Transnational Corporations. London: Routledge for the United Nations.

Jones, G. G., \& De Pinho, R. R. (2006). Natura: Global beauty made in Brazil.

Juul Andersen, T., Copenhagen Business School. CBS, Center for Strategi og Globalisering. SMG, \& Center for Strategic Management and Globalization. SMG. (2008). Multinational Performance Relationships and Industry Context. København. http://dx.doi.org/10.2139/ssrn.1120734

Kirca, A. H., Hult, G. T. M., Roth, K., Cavusgil, S. T., Perryy, M. Z., Akdeniz, M. B., ... White, R. C. (2011). Firm-specific assets, multinationality, and financial performance: A meta-analytic review and theoretical integration. Academy of Management Journal, 54(1), 47-72. http://dx.doi.org/10.5465/AMJ.2011.59215090

Kirca, A. H., Roth, K., Hult, G. T. M., \& Cavusgil, S. T. (2012). The role of context in the multinationality-performance relationship: A meta-analytic review. Global Strategy Journal, 2(2), 108-121. http://dx.doi.org/10.1002/gsj.1032

Knight, D., Pearce, C. L., Smith, K. G., Olian, J. D., Sims, H. P., Smith, K. A., \& Flood, P. (1999). Top management team diversity, group process, and strategic consensus. Strategic Management Journal, 20(5), 445-465. http://dx.doi.org/10.1002/(SICI)1097-0266(199905)20:5\%3C445::AID-SMJ27\%3E3.0.CO;2-V

Kogut, B. (1985). Designing global strategies: Comparative and competitive value added chains. Sloan management review, 26(4).

Kogut, B., \& Zander, U. (1996). What firms do? Coordination, identity, and learning. Organization science, 7(5), 502-518. http://dx.doi.org/10.1287/orsc.7.5.502

Kotabe, M., Srinivasan, S. S., \& Aulakh, P. S. (2002). Multinationality and firm performance: The moderating role of R\&D and marketing capabilities. Journal of International Business Studies, 79-97. http://dx.doi.org/10.1057/palgrave.jibs. 8491006

Li, L., \& Qian, G. (2005). Dimensions of international diversification: Their joint effects on firm performance. Journal of Global Marketing, 18(3-4), 7-35. http://dx.doi.org/10.1300/J042v18n03_02

Lu, J. W., \& Beamish, P. W. (2004). International diversification and firm performance: The S-curve hypothesis. Academy of Management Journal, 47(4), 598-609. http://dx.doi.org/10.2307/20159604

Morck, R., \& Yeung, B. (1991). Why investors value multinationality. Journal of Business, 165-187. http://dx.doi.org/10.1086/296532

Oesterle, M. J., \& Richta, B. T. (2009). Erfolgswirkungen internationaler Unternehmenstätigkeit-Stand der empirischen Forschung und Notwendigkeit verbesserter Forschungsansätze. In Management der Internationalisierung (pp. 51-85). Gabler.

Pan, W.-H., \& Tsai, W.-C. (2012). Internationalization, regional diversification and firm performance: the moderating effects of administrative intensity. International Journal of Business and Social Science, 3(18), 274-282.

Qian, G., Khoury, T. A., Peng, M. W., \& Qian, Z. (2010). The performance implications of intra- and inter-regional geographic diversification. Strategic Management Journal. http://dx.doi.org/10.1002/smj.855

Qian, G., Li, L., Li, J., \& Qian, Z. (2008). Regional diversification and firm performance. Journal of International Business Studies, 39(2), 197-214. http://dx.doi.org/10.1057/palgrave.jibs.8400346

Reeb, D. M., Kwok, C. C., \& Baek, H. Y. (1998). Systematic risk of the multinational corporation. Journal of International Business Studies, 263-279. http://dx.doi.org/10.1057/palgrave.jibs.8490036 
Rugman, A. M., \& Oh, C. H. (2013). Why the Home Region Matters: Location and Regional Multinationals: Why the Home Region Matters. British Journal of Management, 24(4), 463-479. http://dx.doi.org/10.1111/j.1467-8551.2012.00817.x

Ruigrok, W., \& Wagner, H. (2003). Internationalization and performance: An organizational learning perspective. MIR: Management International Review, 63-83.

Sharma, D. D., \& Blomstermo, A. (2003). The internationalization process of Born Globals: a network view. International Business Review, 12(6), 739-753. http://dx.doi.org/10.1016/j.ibusrev.2003.05.002

Sine, W. D., Mitsuhashi, H., \& Kirsch, D. A. (2006). Revisiting Burns and Stalker: Formal structure and new venture performance in emerging economic sectors. Academy of Management Journal, 49(1), 121-132. http://dx.doi.org/10.5465/AMJ.2006.20785590

Tallman, S., \& Li, J. (1996). Effects of international diversity and product diversity on the performance of multinational firms. Academy of Management Journal, 39(1), 179-196. http://dx.doi.org/10.2307/256635

Thomas, D. E., \& Eden, L. (2004). What is the shape of the multinationality-performance relationship?. Multinational Business Review, 12(1), 89-110. http://dx.doi.org/10.1108/1525383X200400005

Williamson, O. E. (1975). Markets and hierarchies. New York, 26-30. http://dx.doi.org/10.1016/B978-0-08-097086-8.73054-6

Yang, Y., \& Driffield, N. (2012). Multinationality-performance relationship. Management International Review, 52(1), 23-47. http://dx.doi.org/10.1007/s11575-011-0095-y 